\title{
PUPUK ORGANIK ENCENG GONDOK DARI DANAU TOBA
}

\author{
Rita Juliani $^{1 *}$, Ruth Fika Ronauli Simbolon², Warmi Hartati Sitanggang ${ }^{3}$, Jon Berghauser \\ Aritonang 4
}

\author{
Jurusan Fisika,Fakultas Matematika dan Ilmu Pengetahuan Alam, Universitas Negeri Medan, \\ Jl. Willem Iskandar pasar V-Kotak Pos No. 1589 - Medan 20221 \\ *Penulis Korespondensi : julianiunimed@gmail.com
}

\begin{abstract}
Abstrak
Danau Toba adalah danau terbesar di Asia Tenggara. Bapak Presiden Republik Indonesia menggalangkan Danau Toba menjadi Monaco Asia, namun keindahan Danau Toba berkurang disebabkan pertumbuhan eceng gondok yang tinggi. Tujuan dari PKM - M membantu masyarakat untuk mengolah eceng gondok yang ada di Danau Toba menjadi pupuk organik yang berguna bagi masyarakat. Metode yang digunakan dalam pelatihan meliputi sosialisasi, pelatihan serta monitoring dan evaluasi. Pengetahuan masyarakat tentang eceng gondok berubah, sehingga masyarakat tahu cara pembuatan pupuk organik eceng gondok yang dapat membantu pertanian dan membantu perekonomian masyarakat. Hasil training eceng gondok yang telah dilakukan, eceng gondok yang melimpah di Danau Toba dapat dijadikan menjadi pupuk organik yang berguna bagi masyarakat serta dapat meningkatkan perekonomian masyarakat daerah. Sehingga dengan kegiatan berkelanjutan Danau Toba akan kembali bersih dan indah.
\end{abstract}

Kata kunci : Pupuk organik, Enceng gondok, Pelatihan, Danau toba

\begin{abstract}
[Organic fertilizers form water hyacinth from Toba Lake] Lake Toba is the biggest lake in Southeast Asia. The president of the republic Indonesia has a plan to make Lake Toba as Monaco Asia. However, the beauty of Lake Toba has reduced as a result of uncontrolled growth of water hyacinth. The purpose of this PKM-M was to help the society to modify water hyacinth as fertilizer organic so that this parasite could be benefical for them. The methods that had been used were socialization, training, monitoring and evaluation. Community awareness of the water hyacinth has changed, so that they know how to produce organic fertilizers form water hyacinth that can help agriculture and economy. From the training that had been accomplished, the abundant water hyacinth can be modified as organic fertilizers which had benefical effect as well as improving the economy of local communities. So if these activities is still being done continiously, Lake Toba would be regained its beauty and cleanness.
\end{abstract}

Key words: Organic fertilizers, Water hyacinth, Training, Lake toba

\section{Pendahuluan}

Eceng gondok (Eichhornia crassipes (Mart.) Solm.) merupakan tanaman gulma di wilayah perairan yang hidup terapung pada air yang dalam atau mengembangkan perakaran di dalam lumpur pada air yang dangkal. Eceng gondok berkembangbiak dengan sangat cepat, baik secara vegetatif maupun generatif. Perkembangbiakan dengan cara vegetatif dapat melipat ganda dua kali dalam waktu 7-10 hari. Satu batang eceng gondok dalam waktu 52 hari mampu berkembang seluas $1 \mathrm{~m}^{2}$, atau dalam waktu 1 tahun mampu menutup area seluas $7 \mathrm{~m}^{2}$. Heyne K. (1987) menyatakan bahwa dalam waktu 6 bulan pertumbuhan eceng gondok pada areal 1 ha dapat mencapai bobot basah sebesar 125 ton.

Perkembangbiakan tanaman yang cepat menyebabkan eceng gondok berubah menjadi tanaman gulma di beberapa wilayah perairan di Indonesia. Kawasan perairan danau, eceng gondok tumbuh di pinggir danau mulai dari $5 \mathrm{~m}$ sampai sejauh
$20 \mathrm{~m}$. Perkembangbiakan enceng gondok dipicu oleh peningkatan kesuburan di wilayah perairan danau (eutrofikasi), sebagai akibat dari erosi dan sedimentasi lahan, berbagai aktivitas masyarakat (mandi, cuci, kakus atau MCK), budidaya perikanan (keramba jaring apung), limbah transportasi air, dan limbah pertanian.

Komposisi kimia dari eceng gondok berupa bahan organik sebesar $78,47 \%$, C organik $21,23 \%, \mathrm{~N}$ total $0,28 \%$, P total $0,0011 \%$, dan $\mathrm{K}$ total $0,016 \%$ sehingga dengan komposisi yang dimiliki maka eceng gondok berpotensi untuk di manfaatkan sebagai pupuk organik yang diperlukan tanaman untuk tumbuh (Rozaq dan Novianto, 2000 dalam Kristanto, 2003).

Salah satu upaya yang cukup prospektif untuk menanggulangi gulma eceng gondok di kawasan perairan danau adalah dengan memanfaatkan tanaman eceng gondok untuk pupuk organik. Eceng gondok dapat dimanfaatkan sebagai bahan pupuk karena 
mengandung selulosa (Joedodibroto, 1983). Pupuk eceng gondok yang dihasilkan berwarna coklat .

Pupuk organik adalah pupuk yang terbuat dari bahan-bahan organik seperti sisa-sisa sayuran, kotoran ternak dan sebagainya dan juga berasal dari mahluk hidup yang telah mati. Pembusukan dari bahan-bahan organik dan mahkluk hidup yang telah mati menyebabkan perubahan sifat fisik dari bentuk sebelumnya. Berdasarkan bentuknya, pupuk organik dibedakan menjadi dua, yaitu: pupuk cair dan pupuk padat (Hadisuwito, 2012). Pupuk organik cair adalah pupuk yang kandungan bahan kimianya dapat memberikan hara yang sesuai dengan kebutuhan tanaman pada tanah (Taufika, 2011). Pupuk organik padat adalah pupuk organik yang secara fisik bentuknya padat dengan kandungan yang sama pada pupuk cair.

Pelaksanaan kegiatan bertujuan untuk mengurangi tanaman liar eceng gondok di Danau Toba sehingga Danau Toba kembali bersih. dan mengubah paradigma masyarakat mengenai eceng gondok sebagai gulma menjadi tumbuhan yang bermanfaat. Keterlaksanaan kegiatan bermanfaat untuk memberikan pengetahuan masyarakat sasaran tentang pemanfaatan eceng gondok sebagai pupuk organik. Pupuk organik eceng gondok dapat dimanfaatkan dalam skala rumah tangga maupun untuk peningkatan perekonomian masyarakat.

\section{Bahan dan Metode}

Bahan yang digunakan untuk pembuatan pupuk organik adalah enceng gondok, EM4 dan plastic hitam. Alat yang dirancang adalah penggiling eceng gondok, bak fermentasi eceng gondok.

Kegiatan Training dilaksanakan di Desa Naburahan Limbong. Metode yang dilakukan meliputi 4 tahap, yaitu tahap sosialisasi, tahap pelatihan, tahap monitoring dan evaluasi (Gambar 1).

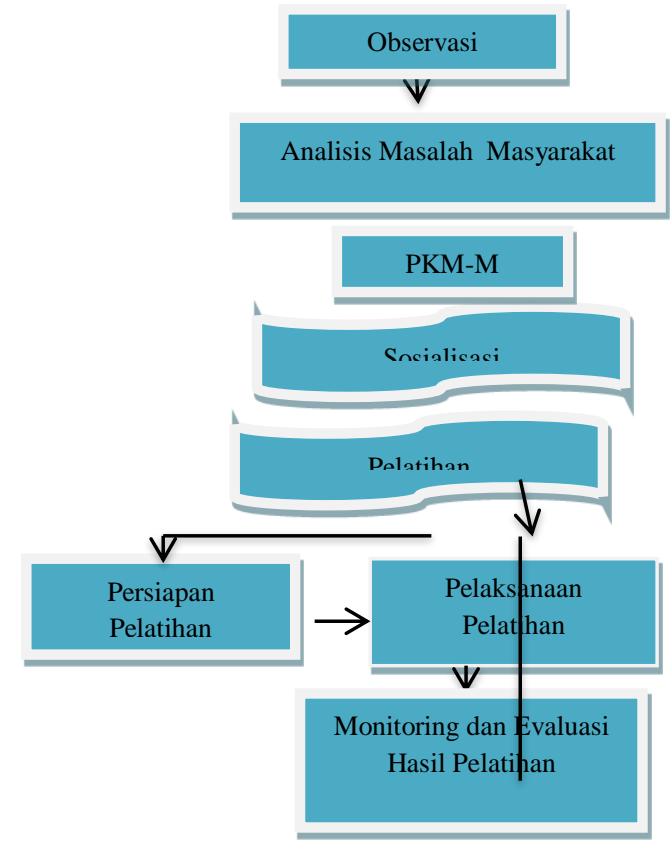

Gambar 1. Diagram alir kegiatan
Tahap Sosialisasi dilakukan dengan pertemuan tim bersama masyarakat dan ibu Kepala Desa. Kegiatan di tahap pertama dibicarakan mengenai waktu, tanggal dan tempat sosialisai dan pelatihan yang akan dilakukan.

Tahap sosialisasi dilanjuttkan dengan memberikan gambaran umum mengenai tumbuhan enceng godok dan pemanfaatannya, di lanjutkan dengan kegiatan pelatihan. Pelatihan terdiri dari 2 tahap yaitu persiapan pelatihan dan pelatihan.

Tahap persiapan pelatihan dihadiri oleh masyarakat dan kepala desa Naburahan Limbong dilanjutkan dengan pengambilan eceng gondok di pesisir Danau Toba dan meletakkannya di tempat pelatihan. Tahap sosialisasi dilakukan dengan memberikan gambaran umum mengenai tumbuhan enceng godok dan pemanfaatannya di lanjutkan dengan kegiatan pelatihan. Pelatihan terdiri dari 2 tahap yaitu persiapan pelatihan dan pelatihan.

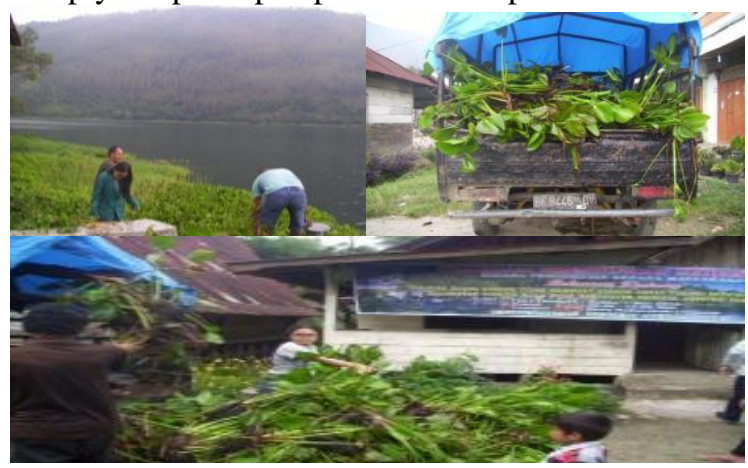

Gambar 2. Pengambilan enceng godok di Danau Toba dan di bawa ke tempat pelatihan

Tahap persiapan pelatihan dihadiri oleh masyarakat dan kepala desa Naburahan Limbong dilanjutkan dengan pengambilan eceng gondok di pinggir Danau Toba dan di bawa di tempat pelatihan yaitu depan rumah salah satu rumah warga. (Gambar 2). Tahap pelatihan pembuatan pupuk di lakukan dengan tahapan pada Gambar 3.

Pelatihan pembuatan pupuk di mulai dengan pengumpulan enceng godok. Enceng gondok selanjutnya di cacah dengan mesin pemootong yang telah di desain oleh TIM untuk mempermudah penghalusan (Gambar 4). 


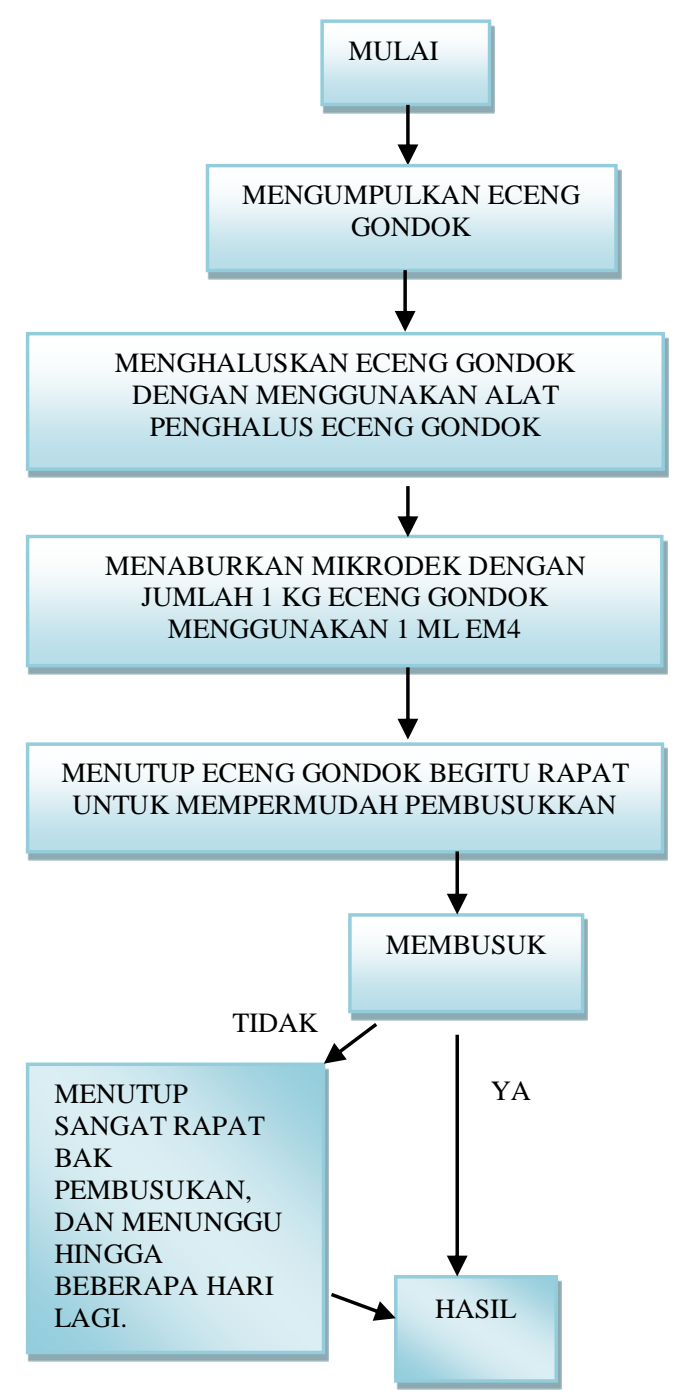

Gambar 3 Diagram pembuatan pupuk enceng gondok

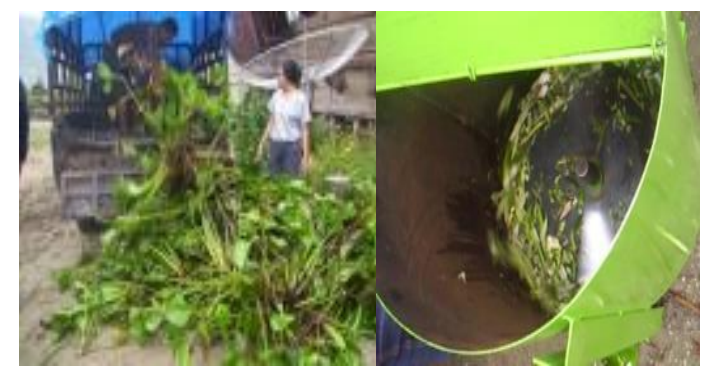

Gambar 4. Mengumpulkan dan pencacahan eceng gondok dengan mesin pemotong.

Enceng gondok yang telah halus ditambahkan EM4 dengan kapasitas $1 \mathrm{~kg}$ eceng gondok $1 \mathrm{~mL}$ EM4 dan ditutup rapat dengan menggunakan plastik (Gambar 5).



Gambar 5. Memasukkan EM4 pada cacahan enceng gondok dan wadah permentasi di tutup rapat.

Tahapan lanjutan dilakukan monitoring dan evaluasi. Tahap monitoring dilakukan untuk melihat hasil pembusukan yang telah dibuat serta evaluasi keberhasilan yang dilakukan masyarakat (Gambar 6).



Gambar 6. Hasil pembusukan enceng gondok

\section{Hasil}

Hasil yang diperoleh dari kegiatan pelatihan adalah pupuk cair dan padatan organik yang dapat digunakan masyarakat setempat untuk tanaman sebagai pengganti pupuk kimia (Gambar 7). Keunggulan pupuk organik adalah tersedianya hara bagi tanaman, baik hara makro maupun mikro yang relatif lengkap dibanding pupuk anorganik. Keuntungan lain adalah dapat meningkatkan kesuburan tanah, menambah unsur hara mikro tanah, menggemburkan tanah, memperbaiki kemasaman tanah, memperbaiki porositas tanah, meningkatkan kemampuan tanah dalam menyediakan oksigen bagi perakaran. Bahan organik memacu pertumbuhan dan perkembangan bakteri dan biota tanah. Secara umum pupuk organik berguna bagi konservasi lahan kritis yang semakin meluas di Indonesia 

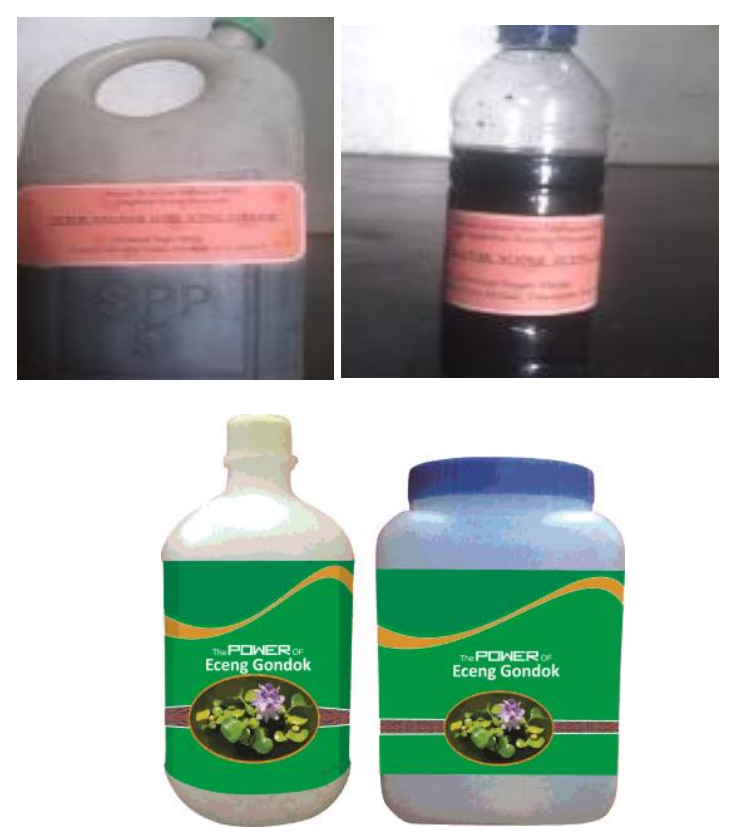

Gambar 7. Hasil pupuk enceng gondok dari Danau Toba

Pupuk organik cair eceng gondok yang di hasilkan di uji kandungan dan dibandingkan dengan persyaratan pupuk organik Permentan No 70 Tahun 2011 (Tabel 1).

Tabel 1. Kandungan pupuk organik enceng gondok dari danau Toba

\begin{tabular}{lllll}
\hline No. & Parameter & Satuan & $\begin{array}{c}\text { Standar } \\
\text { Mutu }\end{array}$ & $\begin{array}{c}\text { Hasil } \\
\text { Uji }\end{array}$ \\
\hline 01. & C-Organik & $\%$ & Min 6 & 0.28 \\
02. & Nitrogen & $\%$ & $3-6$ & 0.05 \\
03. & Phosfor & $\%$ & $3-6$ & 0.009 \\
04. & Besi & ppm & $5-10$ & 3.21 \\
05. & Mangan & ppm & $250-$ & 2.061 \\
& & 5.000 & \\
06. & Seng & ppm & $\begin{array}{l}250- \\
5.000\end{array}$ & 0.261 \\
\hline
\end{tabular}

Hasil uji mutu pupuk organik enceng gondok memiliki kandungan yang sama dimiliki oleh standar mutu yaitu mengandung unsur $\mathrm{C}, \mathrm{N}, \mathrm{P}, \mathrm{Fe}, \mathrm{Mn}$ dan $\mathrm{Zn}$.

Pupuk organik cair pada enceng gondok diberikan pada tanaman cabe, jagung pertumbuhan daunnya bertambah hal ini disebabkan pupuk organik cair enceng gondok membantu menyediakan Nitrogen bagi tanaman. Pupuk organik cair mengandung agensia hayati (mikroorganisme) yang menguntungkan tanaman terutama agensia hayati pengikat Nitrogen dan pengurai Phospat dan Kalium (Kusrinah,dkk, 2016))

Pupuk yang dihasilkan dapat digunakan untuk keperluan sendiri dan masyarakat dapat membuat untuk dipasarkan dan menghasilkan income bagi masyarakat dan jumlah enceng gondok di Danau Toba semakin berkurang. Pupuk cair enceng gondok sebesar 0.5 liter dijual dengan harga Rp. 12.000,-.
Perhitungan biaya yang dihasilkan oleh masyarakat untuk $300 \mathrm{~kg}$ enceng godok basah menghasilkan 100 kg pupuk padat dan 25 liter pupuk cair dengan penambahan EM4 sebanyak 0,33 liter atau dengan biaya Rp. 8250,- Semakin banyak eceng gondok yang dibusukkan maka keuntungan bagi masyarakat cukup besar dan jumlah enceng godok semakin berkurang pertumbuhannya di danau Toba sehingga danau Toba menjadi bersih.

\section{Kesimpulan}

Eceng gondok yang terdapat di Danau Toba dapat diolah menjadi pupuk organik cair dan padatan yang bermanfaat bagi masyarakat di sekitar. Pupuk yang dihasilkan dari bahan organik eceng gondok dapat memberi dampak positif bagi tanah dan tanaman, dan dapat menaingkatkan perekonomian masyarakat dengan menjual pupuk organik. Penggunaan pupuk organik eceng gondok dapat membantu perkembangan tanaman organik di Desa Naburahan. Semakin banyak eceng gondok yang diambil dari Danau Toba untuk dijadikan pupuk, maka Danau Toba kembali bersih dan dapat menjadi objek wisata yang sangat indah.

\section{Ucapan Terima Kasih}

Pada kesempatan ini, TIM berterima kasih kepada RISTEKDIKTI yang mendukung kegiatan ini dan mendanai kegiatan PKM-M. Kepada Universitas Negeri Medan, Bapak Rektor dan jajarannya. Kepada Desa Naburahan Limbong, yang berpartisipasi, kepada BARISTAND yang membantu menguji kandungan pupuk organik eceng gondok, serta kepada ibu Dosen Pendamping yang telah membimbing terlaksananya kegiatan, dan buat semua pihak yang telah mendukung.

\section{Daftar Pustaka}

Hadisuwito, S. (2012) Membuat Pupuk Organik Cair. PT. Agro Media Pustaka: Jakarta Selatan

Heyne, K. (1987) Tumbuhan Berguna Indonesia Jilid II. Badan Penelitian dan Pengembangan Kehutanan. Departemen Kehutanan. Bogor.

Joedodibroto, R. (1983) Prospek Pemanfaatan Eceng Gondok dalam Industri Pulp dan Kertas. Berita Selulosa. Edisi Maret 1983. Vol. XIX No. 1. Balai Besar Selulosa. Bandung.

Kristanto, B, A. (2003) Pemanfaatan Eceng gondok (E. crassipes) sebagai bahan pupukcair. Jurnal UNDIP

Kusrinah, Alwiyah Nurhayati, Nur Hayati.(2016), Pelatihan dan Pendampingan Pemanfaatan Eceng gondok (Eichornia crassipes)Menjadi Pupuk Kompos Cair Untuk Mengurangi Pencemaran Air dan 
meningkatkan Ekonomi Masyarakat Desa

Karangkimpul Kelurahan Kaligawe

Kecamatan

Gayamsari Kotamadya Semarang, Jurnal DIMAS - Volume 16, Nomor 1, Mei 2016.

Taufika, R. (2011) Pengujian Beberapa Dosis Pupuk Organik Cair TerhadapPertumbuhan dan Hasil Tanaman Wortel (Doucus carota L). Jurnal Tanaman Hortikultua. MeiAgustus 2011 